\title{
SIYYASET DIŞI PLANLAMADAN PLANLAMASIZ SİYASETE (Kentbilim Tartışmalarına Katkı)
}

\author{
Prof. Dr. Ruşen KELEŞ*
}

(I)

\section{Kentbilim'de Menfaat, Hak ve Etik}

Ünlü Fransız. Kentbilimci Pierre Merlin, kentleşme sorunlarını çözmekle görevli olan kent yönetimlerinin ve plancıların başarısında, kendilerinin dışındaki etmenlerin önemini vurgularken, Ingiltere'yi ömek gösterir ve der ki, "Ingiltere'de Bayan Thatcher en güçlü yerel yönetimlere karşı verdiği savaşımı kazanabilmek için Kentbilim'i oldürmüştür. Oysa Fransa'da, devlet hizmetinde bulunan kimselerin kentleri edilgin ve başansız kılacak bir söylemle Kentbilim'i öldürmeleri tam bir çclişki olurdu ${ }^{1}$."

Salt bu gözlem bile, siyasal yaşamda doğru ile yanlışı, iyi ile kötüyü birbirinden ayırmanın pek de kolay olmadığını göstermeye yeter.

Kent ve kentleşme sorunlarından çoğunun hem çözümlenmesi (analizi), hem de çözümü, "genel menfaat" kavramının, büyük tartışmaara yol açmayacak biçimde tanımlanabilmesine bağlıdır. Bu ise, ilk bakışta sanıldığı ölçüde kolay olmayan bir iştir. Kimi düşünür ve yazarlar, bu sorunu, "genel menfaat" teriminin ycrine, "adalet" kavramını koyarak çözmeyi önermişlerdir. Adalet Kuramı adlı yapıtı ile bir adalet sağduyusu oluşturmaya yardım edebilecek ilkelere açıklık getirmeğe çalışan John Rawls bunların başında yer alır ${ }^{2}$. Herkes için eşit ölçülerde özgürlük, fırsat eşitliği ve farklı olabilme, üzcrinde durduğu başlıca ilkelerdir. Rawls, eşitlik ile özgürlüğü tek bir kavrama indirgemeğe çalışmakta ve buna "denkserlik (hakkaniyeı) olarak adalet" adııı vermektedir.

\footnotetext{
A.U. Siyasal Bilgiler Fakültesi Öğretim Uyesi.

1 Pierre Merlin, "L'urbanisme: conditions nouvelles, missions pérennes", Vers un nouvel urbanisme: Faire la ville, comment? pour qui?, Sous la direction de Ph. Genestier, La Documentation Française, Paris, 1996, 8.

2 John Rawls, A Theory of Justice, Oxford Unversity Press, Oxford, 1971.
} 
Kentbilim'de sorun, bu kav,ramlann soyut olarak tanımlanmasından çok, kentler için gelişme planları yapmak ve bunlan uygulamakla görevli olanların, planlama ile ilgili davranışlarının meşruluj̧̧ıınu kanıtlarken, bu ilkeleri nasıl kavramakta ve algilamakta olduklanidır.

Anglo-Sakson dünyasında, bir toplum kuralı olarak çok geçerli sayılan "yararcılık", bireylerin seçme öz:giurlügüne dayanan bir liberalizmi her zaman on planda tuttugu halde, Rawls bu liberall gelenekten ayrılmaksızın, onu ussallaştırmağa çalışmışur. "Araçsal liberalizm" kavramını ortaya atarak, bireysel ozzgürluik kavramının yanı sıra, toplumsal kurallanı u'gulanmasında adaleıın önemini vurgulamışur. Bobylece, "genel menfaat" kavramının, "am:sçsal", yani ozzle ilgili algılanışı ile, "araçsal" algılama biçimi arasında bir ayrım yâpraak istemiştir. Bıına bağlı olarak, genel menfaat kavramının, kảş̧ılıklı görüş alışıerişi sonucunda oluşturulması gereken bir kavram olduğ una dikkat çekmiştir. Bu bı̆̆lamda, gelecek kuşaklarla ilgili kaygılara da yer vermesi, Rawls'un düşünce sistemi nin güçlü yönleri arăııında sayılmaktadır.

Genel olarak menfaat bir liş̧inin bir durum, davranıs ya da etkinlik sonucunda sağladığı bireyscl yararların toplımını anlatan bir kavramdır. Bireyler, kentlerin ve kentsel değerlerin kullanıcıları olariak, bu menfaatlerini sürekli olarak gözetir ve artırmayı amaçlarlar. Insanın doğasında yaradılışından beri bulunan bencillik, bu arayış içindeki insana, kendi menfaatini artırma çabası içinde, daha üstiun birtakım kurallarla bağlı bulunduğuna ilişkin bir sorumlulu ju kendiliğinden yüklemez. Kısaca, bireysel çıkarının karşısında ve üstünde, kentin, kor,llinin ve toplumun, kendisininkinden üstün sayılması gereken kimi menfaatleri olabile;e ği, ilk bakışta onı ilgilendirmez. Kişilerin kent toprağı üzerindeki mülkiyet ve kullanırı hak ve özgürlükler: bu gözlemin çok rahatlıkla yapılabildiği bir alandır.

Bireyin menfaati yasalarla güvence aluna aùnmış olduğu takdirde, bu, kendisi için bir "hak" oluşturur. Hakkın. sahic i olan kişi, bu hakkını başkalarına karşı savunabilir, korunmasını isteyebilir. Haklaıın sınırı, başkalarının ve toplumun hakları ve özgürlükleridir. Haklar, sahiplerin: kimi sorumluluklar da yükler. Toplumun, bir başka deyişle, kamunun yararının birzylerin yararından üstïn olduğunu, öyle olması gerektiğini, günümüzde, bütün 'tuikuk sistemleri benimsemiş durumdadır. Dolayısıyle, bireyin menfaatlerinin toplumunkj vle ya da başkalarınınkiyle çelişmesi durumunda tüze (hukuk) kurallarının hakemliğine başvurulur. Kent filanlarının uygulanması sırasında karşılaşılan uyuşmazlıklardan çoğu bu niteliktedir.

Ideal olan durum, bireyin, hak ve menfaatlerinin bir sının olduğunu kendiliğinden bilmesidir. Kenttaş (hemşehri) ve yurttaş olarak yetişme biçimi, kentinin ve çevresinin değerlerine karşı duyduğu sayg, lisaca kentlilik bilinci, davranışlanna yön veren etik kurallàrı biçimlendirmesi gereken stmenlerdir. Kendisini bağlı saydığı etik ve toplumsal değerlerin ağı basması durumın ta, kişiden, bencil davranması, planları yozlaşıınıcı girişimlerde bulunması, kent ve çevre değerlerine zarar vermesi beklenemez. Ne var ki, kişi, bỉreysel ve toplumsal çıkarlar irasındaki adaletli dıngeyi kendiliğinden kurmakta her zaman başarılı olamiyor.

Işte bu koşullarda, hukuk düzeni adına görev yapan kurumların çevrime sokulması zorunlu olmaktadır. Nasıl hukuk her şeyi çözmeye yeterli olamıyorsa, etik de yalnız başına|toplumsal davranışlan yönlendirmeye yetmeycbiliyor. Birbirlcrini bütünlemeleri gereği bu özellikten kaynaklanınaktadır. 
Bu noktada tartışma konusu olarak ortaya çıkan en ơnemli sorun, toplum ya da kamu (herkes) için iyinin, genel ve ortak yarann, bir başka deyişle, toplum yararının ne olduğunu tanımlamak sorunudur. Bu tanımın yapılmasındaki güçlükleri hesaba katanlar, işin zorluğuna bakarak, toplum yararı kavramının var olamayacağını sø̋yleyebilecek olçüde umutsuzluğa kendilerini kaptırabiliyorlar. Oysa, hangi davranışın ve etkinliğin toplum yararına uygun olduğunu belirlemeye yarayan ölçütleri bulmak ve geliştirmek gü̧̧ de olsa, kentleşme, kentsel toprak, kıyıların korunması, doğal ve tarihsel değerlere saygı ve benzeri konularda toplum yararından anlaşılması gerekenler üzerinde görüş birliği sağlamak sanıldığı kadar güç değildir ${ }^{3}$. Asıl tehlike, toplumu devletle ozzdeş sayan eskimiş bir anlayıştan yola çıkarak, burjuvazinin koruyucusu olan devletin öncülüğünde uygulanacak bir "toplum yararı" ilkesinin, toplumun çıkarlarıyla örtüşmeyebileceği kaygısına kapılmaktadır. Günümüzde, haklı ya da haksız olarak devlete karşı oluşturulan genişletilmiş cephenin ortak söyleminde de, toplum yararına karşı duyulan güvensizliǧin izlerine rastlanabiliyor.

\section{Meşruluk Kavramına Dair}

Meşruluk ya da meşruiyet, Türkçe sőzlüklerde, "yasal", "yasaya uygun", "türel" yani törelere, töreye uygunluk biçimlerinde tanımlanıyor. Hemen belirtmek gerekir ki, "yasaya uygunluk" ya da "tüzeye (hukuka) uygunluk" meşruiyetin (legitimacy) biçimsel bir anlatımıdır. Meşruiyetin (meşruluğun) asıl önemli olan öğesi onun özle olan ilgisi, ozle ilgili olan yanıdır.

Öte yandan, meşruluk kavramı, bir kurumdan, bir davranıştan sözedildiğinde kullanılabilecek bir kavramdır. Ömeğin, bir siyasal iktidarın meşru olmasından ya da olmamasından sözedilebilir. Bir davranış meşru olabilir ya da olmayabilir. Bir kimsenin, toplumda geçerli olan kurallar karşısında bir metresle yaşamakta olması, genellikle kabul edilen değer sistemleri karşısında meşru sayılmayabilir.

Aynıca, kimi etkinliklerin meşru sayılıp sayılmaması da olası görülmektedir. Belli bir plan belgesinin, planlama etkinliğinin meşruluğu, belli nedenlerin varlığı durumunda sorgulanabilir. Ama, bireysel plan ya da planlama çalışmalanndan yola çıkarak, bütün bir mesleği, plancılık uğraşını gayri meşru saymanın ve bu yöndeki çabaların doğru olduğunu sanmıyorum. Hele de, bir bireyin, bir meslek odası üyesinin, plancının meşruluğu teriminin, ne dilimizin yapısına, ne de meşruluk kavramının özüne uyduğunu saniyorum.

Bununla birlikte, gecekondu yapma sürccinin meşruluğu (doğrulluğu) tartışılabilir ve tartışılmaktadır. Geçmiş yıllarda yazmış olduğumuz kimi kitaplarda, gecekondulara, "gayri meşru birleşmelerden doğmuş çocuklar" gözüyle bakuğımızı belirtmiştik. Çünkü, zaman zaman çıkarılan yasalarla, bu yasa dıß̧ı çocukların neseplerinin düzeltilmesine, yurttaşlık haklarını kullanabilmelerine olanak veren aile ilişkilerinin kurulmasına, topluma kazandınılmaları için meşrulaşurılmalarına çalışılmışır.

${ }^{3}$ Ruşen Keleş, "Kentleşme ve Kamu Yararı", Kent ve Slyaset Üzerine Yazılar: 1975-1992, IULA-EMME, Istanbul, 1993. 


\section{RUŞEN KELES}

Gecekondu yapımında, bir bakış açısına göre, hem: yasaya aykırılık vardır; hem de, gecekondu yapımı meşru değildir. Bir başka bakı ą̧ısından ise, gecekondu yapmak, yürürlükteki yasalara aykırı olnakla birlikte, gayri meşru bir davranış değildir. Çünkü, genis halk toplulukları, barınma gereksinmelerini karşılayabilmek için gecekondu yapmaktan başka çare bulamıyorlarsa ve bu insanların bu barınakları yapmaları durumunda toplumun büyük bir kesimi bundan vicdanî bir rahatsızlık değil, tersine bir vicdan huzuru duyuyorlarsa; burada meşru olmayan bir durumdan, etkinlikten sözedilemez. Bu örnekle belirımek istediğim, meşruiyet kavramının, bakış açısına göre, kişiden kişiye, kültürden kültüre ve zaman içinde deģ̧işmekte olan bir içeriğe sahip bulunduğudur.

Planın bir hukuk kuralı olduğunu hepimiz biliyoruz. Plan, Yönetim Hukukunda, bir "düzenleyici işlem", "kural-işlem" olarak adlandırılıyor. Dolayısıyla, plan, ilk bakışta, uyulması gereken bir tüze kuralıdır. Ancak, şimdi öyle bir durumda bulunuyoruz ki, bir plana sahip olmak ve kentleşmeyi bir plana uygun olarak gerçekleştirmek, kural olması gereken bir durum ve etkinlik iken; çoğu ke r., bunun tam tersinin geçerli olduğunu görüyoruz. Bir başka deyişle, plansızlık ve plansız gelişme kural; plan ve planlı gelişme ise, istisna durumuna gelebiliyor. Bu durumda, Charles Haar'ın, 1950'li yıllarda, "Sürekli olmayan bir anayasa" (an Impermanent Constitution) olarak nitelcyerek, hem uyulması zoruhluluğuna, hem de kolc.y değiştirilemiyeceğine özelliğine dikkat çekmek istediği planın meşruluğu tartışılabilir duruma geliyor ${ }^{4}$.

Siyaset Bilimi'nde, meşru sözcüğünü, genellikle, siyasal iktidarların ayakta kalmalarına, varlıklarını sürdürebilme olanaklarına bağliıyarak kullanıyoruz. Bu yönden, "yasal yönetim" ve "meşru yönetim" birbirlerinden ayrılmaları gereken iki kavram olarak çıkıy,or karşımıza. Yasal (kanunî, legal) yönetim, pozitif hukuka, yürürlükteki hukuk kurallarına uygun olarak kurulmuş ve sürmekte olan yönetimleri anlatıyor. Ne var ki, pozitif hukuka uygun olan yasal bir yönetim, toplumbilimsel ve siyasal açıdan her zamán meşru olmayabilir.

Meşru (legitimate) yönetim, ona tâbi olanlar tarafından meşru olarak kabul edilen, toplumda geçerli ve yaygın olan meşruluk inancına uygun düşen ve kamu duyuncunu rahatsız etmeyen bir iktidardir.

Siyaset felsefecisi Hans Kelsen'e göre, yasallık ve meşruluk eşit kavramlardır. Bu, katı bir pozitivist yaklaşımdır. Oysa, deneyimler, her iki kavramın aynı şeyler olmadığını gösteriyor. Diktatörlüklerde, diktatörün istenci ve buj'rukları koylayca yasa biçimini alablliyor. Ama, bu durum, o dikta rejiminin halk tarafından meşru bir iktidar olarak benimsenmekte olduğu anlamına geliyor. Yasallık, hukukî ve biçimsel bir meşruluktur. Dolayyısıyla, geniş anlamda meşruluğun temeli olamaz. Meşruluk, iktidarın hem kaynağı, hem de kullanılışı açısından ónem taşır ${ }^{5}$.

${ }^{4}$ Charles M. Haar, "The Master Plan: An Impermanent Constitution", Law and Contemporary Problems, Vol. 20, No: 3, Summer 1955, 352-418.

${ }^{5}$ Munci Kapani, Siyaset Billmine Giriş, Ankara, 1980. 
Carl Friedrich'in haklı olarak belirttigyi gibi, 1789 'da, Fransa'da 16. Louis'nin iktidarı biçimsel anlamda yasaldı, ama meşruluğunu yitirmiş bulunuyordu. Humeyni de 1970'lerin sonunda devirdiği Şah yönetiminin meşruluğunu yitirdiği iddiasındaydı.

Türkiye'de 27 Mayıs 1960 tarihinde iktidan deviren silâhlı güçler, siyasal iktidan, "meşruluğunu yitirmiş bir iktidar" olarak nitcleyerck iktidara el koymuşlard. Buna benzer ornekler başka ülkelerden de verilebilir. Demek oluyor ki, bir siyasal iktidar, a) kendi hukukî meşruluğunun dayandığı hukuk kurallarını çiğnerse ve b) yürürlükteki kurallara uymakla birlikte toplumun değişen meşruluk anlayış ve inancı karşısında destę̆ini yitirirse, varlığını sürdüremez.

Görülmektedir ki, meşruluğun tek, mutlak ve evrensel geçerliliği olan bir ölçüsü yoktur. Kavram, zamana ve mekâna göre değişmektedir. Toplumun üyelerinin büyük bir çoğunluğunun görüş birliği anlamına gelen temel oydaşma (consensus), meşruluk kavramıyla yakından ilgilidir. Max Weber'in de belirttiği gibi, meşruluğun özünde, otoriteye bağlı olanlar tarafından beslenen inanç ve iktidarın doğru ve hakhı olarak kullanıldığı yolundaki kanı vardır. Bu yönden bakıldığında, meşruluk kavramına siyasal ve ideolojik anlamda bir ölçüt bulmak kolay olmamakla birlikte, insan haklarına, temel ozgürlüklere, toplum yararına, kent ve çevrc değcrlerine saygı, bu bağlamda akla gelebilecek kavramlardır. Bunların hemen hemen hepsinin, değer yargılarıyla ilgili bulunduğunu söylemck gercksizdir.

Bu nedenle de, kamu duyuncunun dayandığı etik değer ve ölçünlerin eğitim vb. araçlarla yüksseltilmesine çalışmak önem taşımaktadır. Bu durumda, gecekondunun kendisi marjinal olmaktan çıkmı̧ ve çoğunluk durumuna gelmiş bile olsa; halkın, gecekondu yapmayı zorunlu kılan nedenler karşısındaki tavrı, o etkinliğin meşru sayılmasına yarayabilir. Öte yandan, kamu malını gelecek kuşakların yararlanmasına olanak bırakmayacak biçimde yağmalayan arsa mafyası denilen güçlerin etkinlikleri, kamu duyuncunda hiçbir zaman haklılık bulamayacaktır. Bireyin ve toplumun bugünkü ve gelecekteki çıkarları arasındaki dengenin dayandığı ölçütler, gerçekten demokratik bir toplumda, haklılığını toplumsal oydaşmada bulabileccktir ${ }^{6}$.

\section{Plancının Sorumluluğu}

Plancının etik sorumluluğu, konumuzla çok yakında ilgili, önemli bir konudur. Acaba bu mesleğin üyeleri, bir mesiek etiğine sahip olmak ve bunun gereklerine uymak zorunda değil midirler? Benim gibi, Türkiye'de kentleşme olayının son 40-45 yılını yaşamıs, yakından görmüs ve değerlendirme yapabilecek durumda olanların anımsayacaklan bir örnck, bu bağlamda önem taşımaktadır.

"Istanbul'un Imarı" adı verilen yıkım olaylarında, 1950'li yıllarda, zamanın Başbakanı Adnan Menderes'c, birtakım mimarlar, mühendisler ve kent plancılan yardımcı olmuşlar ve bu uygulamalar sonucunda birçok semtler ve tarihsel değerler yok olup gitmiştir. Acaba, o güçlï siyaset adamına yardımcı oldukları sırada, bu mimar, mühendis

6James M. Buchanan and Gordon Tullock, The Calculus of Consent: Logical Foundations of Constitutional Democracy. University of Michigan Press, Ann Arbor, 1962, 283-317. 
ve kent plancılarının, uymaları, kendilerini bağlı saymalan gereken bir meslek etiłinin kuralları söz konusu olmamalı mıydı? ${ }^{7}$ Bunlar, daha sonraki yıllarda da, Boğaziçi'ni, Bebek'i, Istanbul'un Anadolu yakasırı çok aşın yoğunluklarla taş yığınına çevirten siyasa adamlarına karşı çıkmamakla kalnıayıp, akıl vermekte duraksamayan, kimi meslek odalannın üyeleri değiller miydi?

Daha çok yakında, ülkemizde, kimi yasalarla, yeminli özel teknik bürolar yarafildı ve kendilerine, yerel hizmetlerle ilgili kimi kamu görevlerinin ycrine getirilmesi işi verildi. Bu bürolan yaratan ve savunanların yapuklarına karşı kimi meslek odalannın büyừk bir tepki göstermediği, benim dikkatimden kaçmamıştur. Bu düzenlemelerle meslektaşlarına is alanları açılınıs da olsa, kendilerini belli etik kurallarla bağlı sayanların, yalnız birey olarak de ğil, sivil toplum örgüıleri olarak bu türlü uygulamalarnn kaşısında olmaları beklenirdi. Yoksa bunlar, tepki gősterilmesi gereken yanlış davranışlar sayılmıyor muydu? Geçmişte, Minarlar Odası'nın Boğaz. Köprüsü ve otoyollar gibi konụlarda gösterdiği duyarhılı örnekleri, kanımca, meslek etiği yönünden çok anlamlı ömeklerdir.

Bunun gibi, Kent Plancılan Odası'nın, 404ti sayılı Özelleştirme Yasasıyla yaratılan durumun kent planlarını ve kent plancılığını, sağlıklı kentleşmeyi, kamusal toprak iycliğini nasıl etkileyeceği konusunda duyarlılık göstererek, hiç olmazsa kendi üyeleri arasında bir toplanı düzenlemiş olmasını saygı ve takdirle karşılanması gereken bir duyarlı davranı̧̧ ömcği olarak göıdüğümü belirtmek istiyorum.

\section{Plan ve Planlama Anlayışları}

Osmanlı Imparatorluğu döncmi dışta bırakılacak olursa, Türkiye'de kent planlamasının tarihçesini 1920'lerden başlatmak olası görünmektedir. Ülke çapında ekonomik kalkınma planı hazırlamak konusundaki ilk ģirişim ise, 1930'lu yıllann başına rastliyor. 1960'larda gündeme gelen bölge çapında planlama çalışmaları, üçüncü sırada bulunuyor.

1961 Anayasası'nın 41. maddesi, "iktisäî ve sosyal hayatın düzeninden" sözederken, "Kalkınma planı yapmak devletin ödevidir" demiştir. Ayrıca, o Anayasanın 129 ! maddesinde de, "Íktisadî, sosyal ve kültürel kalkınma plana bağlanır" deniliyordu. 1982 tarihli Anayasanın 166. maddesinde de, "Ekonomik; sosyal ve kültürel kalkınmayı, özellikle sanayiin ve tarımın yurt düzeyinde (yüzeyinde) dengeli ve uyumlu biçimde hızla gelişmesini, ülke kaynaklarının döküm ve değgerlendirilmesini yaparak verimli şekilde kullanılmasını planlamak, bu amaçla gerekli teşkilâtı kurmak Devletin görevidir.... Kalkunma girişimleri, bu plana göre gerçckleştirilir" deniliyor.

Başka ülkelerin birçoğunda olduğu gibi, ülkemizde de, her basamaktaki planlama, her zaman siyasetin dışında tutulması gercken bir uğraş olarak algılanımıştır. Oysa, yaşánan deneyimler, haklı olarak iki sorunun yanıtının aranmasını zorunlu kılıyor: Planiama uğraşı siyasetin dışında tutulabilir mi? Ve de tutulmalı mıdır? Bu sorulann her

${ }^{7}$ Sıddık Sami Onar, "Imar Faaliyetinin Istanbul'da Ortaya Çıkardı̆̆ı Meseleler". Cumhuriyet, 5 Haziran 1957. 
ikisine de olumlu yanıt vermek olanağı bulunmadığı, deneyimlerle açıkça görülüyor. Planlama ile siyaset, bir anlamda, içiçe olan, öyle olmaları gereken uğraşlar olarak görülüyor.

Böyle olduğu içindir ki, 1960'ların başlarında Devlet Planlama Örgütü kuruldugunda, bu örgütün organlanından biri olan Yüksek Planlama Kurulu, plancı bürokratlarla siyaset adamlarını biraraya getiren ve bu yakınlaşmayı, etkileşimi să̆lamayı amaçlayan bir yapıya sahip kılınmıştı. Sonradan bu anlayış terkedilmiş ve bizce yanlıs olarak, teknokrat plancılar bu sürecin dışına çıkarılmışlardır.

Planlamayı siyasal güçlcrin dışına atmak ne denli yanlış ise, plancıların siyasal kadroların buyruğunda partizanlaşmalarına göz yummak da o denli yanlışur. Söz konusu olan, sağlıkli bir iletişimin kurulması gercğidir. Eğer planlama süreci siyasal süreçlerin bir parçası ise, bu sürece birtakım değerlerin yansıması, yansıtılması kaçınılmazdır. Bu değerlerin, ne ölçüde, kimlcrin değerleri olacağı sorusu yanıtlanması çetin bir sorudur. Bu değerler, daha çok plancının, bir meslek odasının, bir siyasal partinin, belli bir azınlığın değerleri mi, yoksa toplumun büyük bir çoğunluğunun sahip çıkmağa çalıştığı, savunduğu değerler mi olacakur? Ve bu değerler nasıl saptanacak, planlama sürecine nasıl yansitulacakur? Asıl güçlük de buradadır.

Planın teknik ve siyasal öğcleri vardır. Kimi yazar ve düşünürler, siyasal ögelerin, teknik öğeleri ikinci plana iterek onların yerini almasını önlemck amacıyla, değişik kurumsallaştırma önerileri yapmışlardır. Robert Walker, planlama sürecini seçilmişlerin etkilerinden uzaklaştırabilmek için, görevin, "bağımsız planlama yarkurullarına (komisyonlarına)" bırakılmasını önermiştir ${ }^{8}$. Robert Goodman ise, yapıtının bir bölümüne "Siyaset Batağından Kurtulmak" (Salvation from Politics) adını vererek onunkine benzer modeller önermiştir ${ }^{9}$. Ne var ki, hem başka ülkelerin, hem de bizim deneyimlerimiz, a) ne plan hedeflerinin saptanmasinda, b) ne hedef belirleme yöntemlerinin belirlenmesinde ve c) ne de uygulamanın yönlendirilmesinde siyasal etkenleri gözden uzak tutmanın olanakı olmadığını gösteriyor ${ }^{10}$.

Planlamayı ve planlı çalışmaları günlük ve doğrudan çıkar hesaplarının etkilerinden koruyabilmek için, yargı, plancıların çok yakından tanıdıkları bir kurumdan yararlanır: Bilirkişilik. Bu kurum, yansızlığına yürütmeden daha çok güven duyulan bir kuruma, yargıya yardımcı olmak, konunun tcknik boyutlarının değerlendirmelere kaulmasını sağlamak, kısaca, yargılama sürecini nesnelleştirmek için oluşturulmuştur. Yarǵının da bütün öteki toplumsal kurumlar gibi, toplum yapısının bir ürünü olduğu anımsanır ve mahkemelerin bilirkişi yazanaklarıyla bağlı olmalarının bir zorunluluk olmadığı hesaba katılırsa, bu kurumun da tam bir güvence oluşturamayacağı belirtilebilir. $\mathrm{Ne}$ var ki, uygulama, yargının bilirkişi görüşlerine genellikle saygılı davrandığını gösteriyor.

\footnotetext{
${ }^{8}$ Robert Walker, The Planning Function in Urban Government, University of Chicago Press, Chicago, 1951.

${ }^{9}$ Robert Goodman, After the Planners, Penguin, Harmondsworth, London, 1972, Chapter 6 (183-210).
}

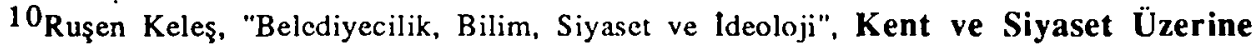
Yazilar, op. cit, 54-62. 
Yönetimi partizanlığın ctkilerinden kurtarmak savıyla zaman zaman siyasal iktidarı ele geçiren askerî cuntalar, bu amaçlarını gerçekleştirmek için "partilerüstü", "teknisyenlerden oluşan" hükümetler kurmuşlardır. T'eknokratlardan oluşan bu tür bakanlar kurullarının, ülkemizde, yürütmeyi siyasetin dışına çıkarmakta başarı göstèdiğini kimse öne süremez. Çünłü onlar da, en az öteki kişiler kadar, kendilerini siyasłal güçlerin buyruğuna vermişlerdir. 27 Mayıs'ta da, 12 Mart'ta da, 12 Eylül'de de, bunuh türlü örnekleri açıkça görilimüş̧ür. Askerî cuntalărın kendileri bile, gecekóndu aflar ve benzer nitclikteki kararlarıyla, kendilerini popülizmin çekiciliǧinden ve günlük siyasetten uzaklaşuramamışlardır.

O halde ne yapmak gerckiyır?

1. Belediyecilik ve o çerçevede ele alınan plancılık, salt teknik konular olarak algılandıkları zaman, başarılı bir plancılık yapılamadı̆̆ görülüyor. Plancılarımız ve teknókratlarımız siyaset adamlanna ve siyasal kadrolara -bunlann günümüzdeki nitelikleri bir yana bırakılacak olursa. çoğu kez küçümseyici gözlerle bakıyorlar. Siyasal süreçlere ve kàdrolara güven duymáyan plancı onlarla birlikıe çalışmak zorunda oldugunu, bu zoruńluluğun sistemden kaynakliandığını unutuverinsc, kendi kafasında yaratığı ideal âlemın birden çöküverdiğini görüp düş kırıklığına uğruyor.

Bu plancılar, uğraş arkadaşlarıyla kolayca anlaşab:liyor, aynı dili konuşabiliyor; ama, dilek, özlem ve önerilerini bir türlü gerçckleştirmek olanağını bulamıyorlar. Çünkü, kullandıkları dili, halkın ve özellikle de politikacının anláyabileceği bir biçime sokmak zahmetine katlanmıyorlar. Başarısızlığın ardında kuşkusuz önemli başka etmenler de var. Ama bu durum, sonuç olariak, plana kåş̧ı çıkanlarla savaşımlanında plancılann yalnız ve güçsüz kalmalanna yol açabiliyor.

2. Bunun karşıtı olan tutuın ve anlayış, teknokrat plancıyı politikacının, halktan yőnelme görevi almış, seçimle işbaşına gelmiş olan kişi ve kurulların buyruğu altında görme anlayışıdır. Teknokratın patronı politikacı olunca, halkın önemi, kuramsal olarak, artmiş olur. Siyasal güçler dengesi içinde, teknokrat, bir ölçüde, kendisine verilen görevi sessižce yerine getiren bir kişidir artık. Bilgisini, teknik yeteneklerini, kişiliğini görevine yansitabilmesi, patronunun çizdiği sınırlara ve ona tanıyacağı özgürlüge bağlıdır. Buyruğu altında olduğu politikz:cının isteklerine bilimsel gerekçeler hazırlamak, bu modèle uyan plancının başlıca gëırevidir. Zaman zaman da "partizanlığı ussallaştırmak" gibi bir görevle karşı karşıyadir. Çünkü o bir bürokratır. Yaptıklarının kendi meslek etiği anlayışına ters gelmesi durumunda görevini bırakmaktan başka çaresi yoktur.

Politikacıyı bilgisiz, nüfuzunu her zaman kötüye kullanan, onnyargılı ve yanlı; plancıyı ise, aklı, akılcılı̆̆ı̆, yar:sılı̆̆ı, uzmanhı̆̆ ve uzakgörüşlülügü temsil ediyor sayan görüş, günümüzde, ६,iderek daha az yandaş bulabiliyor. Hepsi de aynı harmandan paketlenmiş tütün gibidirler. Anıa, siyasal baskılara, plancılar, yerel politikacılardan elbette daha dayanıklı olma şansına sahiptirler. 
Plancı-politikacı yakınlaşmasının, başarılı planlamanın ve belediyeciliğin ơn koşulu olduğu unutulmamalıdır. Bu ilişkiyi sağlıkı bir biçimde kurmanın koşullan ise şunlardır ${ }^{11}$ :

a) Plancı, politikacıya biraz daha fazla benzemeye çalışmalıdır. Kişiliğini yitirecek olçüde politikacının hizmetine girecek ya da partizanlığa arą̧ olacak değildir. Siyaset olayını, siyasal güçler dengesini yakından kavrayacak duruma gelecek, patronunun siyasal ideolojisi ile davranışlan arasındaki tutarsızlıklan görebilecektir. Önerilerini; siyasal kişi ve kurullara, bir kavram ve dil çapraşıklığı içinde sunarsa, hem kendini, hem de patronunu zor duruma sokar.

b) Ikinci koşul, politikacının kendisine çekidüzen vererek, teknokrat bir plancı gibi davranmaya alışmasıdır. Bu, politikacının çalış̧ırmakta olduğu plancıyla iletişim kurabilecek ölçüde teknik konulara yakınlaşmasını, planı ve planlı çalışmayı kendi hareket özgürlüğünü kısıtlayan bir etken gibi görme eğilimini terketmesini zorunlu kılar.

Politikacı, plancıyı, kendisine oy yitirten değil, oy kazandıran bir yardımcı olarak gördü mü, onunla işbirliği yapmaktan çekinmeyecekțir! Ancak, bu işbirliğinin, toplumsal adalet, ekonomik ussallık, genel yarar, doğal ve tarihsel değerlere saygı gibi birakım sınırları olduğunu gözden uzak tutmamak gerekir.

c) Üçüncüsü de, halkı, kentinin yönetimine ve planlama sürecine olabildiği ölçüde katmağa çalışmaktır. Katılım yalnız bürokratın, plancının ve siyasetçinin görevlerinin yerine getirilmesini kolaylaştırmakla kalmaz, kentlinin elindeki bilgilerin, onun eğilim ve özlemlerinin de yönetime yansıması yoluyla, planlamanın kalitesini yükseltir. Katılımın, planlamaya meşruluk kazandırmak ya da planlamanın meşruluğunu sağlamak bakımından taşıdığı değer, kuşku yok ki, daha başka değişkenlerle de ilgili bulunmaktadır ${ }^{12}$.

\section{Plan Düşüncesin Saygı ve Meşruluk Kaygısının Sonucu}

1. Plan hazırlama ve uygulamanın özel koşulları, başka ülkelerde de, kimi düşünürleri, planların meşruluğunu sorgulamağa itmiştir ${ }^{13}$. Eğer, ağırlık kazanacak olan gơrüş, planlarnn, meşruluğunu (doğrulluğunu) yitirmiş bulunduğu olacaksa, bunun, plan düşüncesine ideolojik ve başka nedenlerle karşı olanlara gü̧̧ kazandıracağına kuşku duymamalıdır. Gerçekten, ülkemizde, her türlü plan düşüncesi, 35 yıldır, bir kısım çevrelerce tepkiyle karşılanıyor. Plan ve müdahalecilik, rejimin ideolojisiyle bağdaşmaz bulunuyor. Planların, gerçektc, çoğu kez, karışmacı ve yönlendirici olmak yerine, olup bittileri yasallaşıımak için yapılmakta olduğu anımsansa, bu tür kaygılara belki de gerek kalmayacak.

${ }^{11}$ Anthony James Catanese, The Politics of Planning and Development, Sage Library of Social Research, No: 156, London, 1984.

12 Ruşen Keleş. "Kentsel Katılım Nedir? Ne Değildir?", Kent ve Slyaset Üzerine Yazilar, 20-34.

13 Cliff Hague, The Development of Planning Thougth: A Critical Perspective, Hutchison, London, 1984, 222-259. 
2. Bu gözlem doğॅu olmakla birlikte, planların ve planlamanın meşruluğundan kuşku duymanın uç ölçülere vardłırılması, plansızlığın plana yeğlenmesinden başka bir anlam taşımayacakur. Planı düzencesinin (disiplininin), düzencesizlikten daha iyi olduğu görüşü bir yana itildi mi; bu kez, plansızlığın ve đüzensizliğin meşruluğu topluma bir değor olarak benimsetilmej̧e çalışılacak. Küreselleşen dïnyada, batunın zengin ülkelerinin az gelişmiş yoksul ülkelere benim.setmeğe, dayatmağa çalıştıkları görü̧ de bu değil midir?

Bir başka yerde de belirttig̨im gibi ${ }^{14}$, Türkiyc'de, plana ve plan düşüncesine saygıda, son 35 yılda büyük zikzaklar çizilmiştir. 1960-1980 döneminde, plana karşı ortülü negatif bir tavrın sergilendį̧,i göze çarpar. 1980 sonrasında ise, biraz dünyadaki gelişmelerden de etkilenerek, plan karşılı $\nvdash_{1}$, resmî çevrelerde bile açıkça ve pervasızca dile getirilmeğc başlanmışıı. Plansızlık, hükümet politikası durumuna getirilmiştir. "Bize plan değil pilâv gereklidir" divenlerin özlemleri, bu dönemde resmîleşmiştir. Bugün artık, planlamanın, devlet siyasetirin önemli bir aracı olmaktan hemen hemen çıkmış oldư̆gu açıkça görülüyor. 1982 tarihli Anayasada bile, planlamanın yeri, 1961 Anayasası'nda olduğu ölçijde güçlü ve saygnn değildir. Bi: eski plancı dostun da belirttiği gibi, bugün "planlanmış bir plansızlık"la karşı karşıya bulunduğumuz söylenebilir ${ }^{15}$.

Bunun gibi, liberalleşme, küreselleşme ve özelleştirme gibi kimi moda akımların etkisi altında, devleti küiçültme, her türlü kamu etkinliğine cephe alma dönemi başlamıştır. Devletle birlikte kent yönetimlerinin küçültülmesi (etkinliklerinin azaltılması) da gündmdedir. Bu gelişmelerin, kentlerin düzenli gelişmesini sağlamayı amaçlayan plalama çalışm:alarının başarısızlığında doğnıdan doğruya etkileri vardır. Arsa ve kıyı yağmacılığı, doğal kaynaklar ve çevre değerleri karşısında duyarsızlık, yeni bir dünya görüşünün toplumumuzda ald.ığı biçimle yakından ilgili yozlaşmalardır.

Bu arada, belediyesiliğj dahaz demokratik, katılımıı, üretici, birlikçi, rant dağıtucı değil, fakat rantlara kaını adına el koyucu duruma getirmeyi amaçlayan "yeni belediyecilik" anlayışını 20-25 yıl önce ortaya atmış olan siyasal kadrolar bile, kendi geliş̧tirdikleri ilkeleri savunmak cešretini gösteremez olmuşlardır.

Bütün bu koşullar altında, kent planlamasının ne anlamı kalmıştr? Haksızlıkları yasallaşurmanın aracı clarak kı:llanılan bir planlama mekanizmasının varlığını korumanın yararsız olduğu öne sürülebilir. Bir başka deyişle, meşruluğunun sorgulanması yolundaki ç:abalar, várlığina son verilmesi istemleriyle de sonuçlanabilir. Tıpkı, meşruluğunu yitiren siyasal iktidarırın ortadan kaldırılması için devrim yapan antidemokratik güçlerin, yaratıkları fiilî durumların sonradan yasal bir değer kazanmasında olduğu gibi.

Bu yeni bir görüş değildir. Ülkemizde, planlamanın olupbittileri yasallaştırma işleyi gördüğünü, kent planlarının kentsel gelişmeye yön vermek yerine, bu işi rantiyelerin yapmakta oljukları, planların ise olupbittileri plana uydurmaktan öte bir

${ }^{14}$ Rụ̧sen Keleş, "Planlı Dönemin Plansız Kentleşmesi: Son Otuz Yılın Bilânçosu", Dünya Şehircilik Günü Kollokyumu, Izmir, 1992.

15 Ali Nejat Ölçen, "Planlanan Plansızlık", Türkiye Sorunları, Sayı: 11, Ekim 1995. Ankara, 40-45. 
işlev görmediği gözlemi yapılalı en az otuz yıl oluyor. Şimdi, bu gőzleme dayanarak, plancıların, tek tek, ya da bir uğraş örgütü olarak, kendi varlık nedenlerini bile tehlikeye sokacak meşruluk tartışmaları yapmaları, etik açıdan saygın bir davranış sayılsa bile, toplumun plana ve düzene gereksinmesi konusunda otedenberi şaşı bakmış olaníara haklılık kazandıracak boyutlara vardıılmamalıdır. Yapılması gereken, başarısızlığın iç ve dış koşullarını azalıma şansı yaratacak savaşımı durdurmamaktır. 